\title{
Antibiofilm Activity of a Trichoderma Metabolite against Xanthomonas campestris pv. campestris, Alone and in Association with a Phage
}

\author{
Marina Papaianni ${ }^{1}$, Annarita Ricciardelli ${ }^{2}$, Andrea Fulgione ${ }^{3}$, Giada d'Errico ${ }^{1}$, Astolfo Zoina ${ }^{1}$, \\ Matteo Lorito ${ }^{1,4}$, Sheridan L. Woo ${ }^{4,5}\left(\mathbb{D}\right.$, Francesco Vinale ${ }^{4,6, *(\mathbb{C})}$ and Rosanna Capparelli ${ }^{1}$ \\ 1 Department of Agricultural Sciences, University of Naples Federico II, 80055 Portici (NA), Italy; \\ marina.papaianni@unina.it (M.P.); giada.derrico@unina.it (G.d.); zoina@unina.it (A.Z.); \\ lorito@unina.it (M.L.); capparel@unina.it (R.C.) \\ 2 Department of Chemical Sciences, University of Naples Federico II, 80125 Naples, Italy; \\ ananrita.ricciardelli@unina.it \\ 3 Istituto Zooprofilattico Sperimentale del Mezzogiorno (IZSM), 80055 Portici (NA), Italy; \\ Andrea.Fulgione@izsm.it \\ 4 Institute for Sustainable Plant Protection, National Research Council, 80055 Portici (NA), Italy; woo@unina.it \\ 5 Department of Pharmacy, University of Naples Federico II, 80131 Naples, Italy \\ 6 Department of Veterinary Medicine and Animal Productions, University of Naples Federico II, \\ 80137 Naples, Italy \\ * Correspondence: frvinale@unina.it; Tel.: +390812539338
}

Received: 16 March 2020; Accepted: 22 April 2020; Published: 25 April 2020

\begin{abstract}
Biofilm protects bacteria against the host's immune system and adverse environmental conditions. Several studies highlight the efficacy of lytic phages in the prevention and eradication of bacterial biofilms. In this study, the lytic activity of $X \operatorname{cc} \varphi 1$ (Xanthomonas campestris pv. campestris-specific phage) was evaluated in combination with 6-pentyl- $\alpha$-pyrone (a secondary metabolite produced by Trichoderma atroviride P1) and the mineral hydroxyapatite. Then, the antibiofilm activity of this interaction, called a $\varphi \mathrm{HA} 6 \mathrm{PP}$ complex, was investigated using confocal laser microscopy under static and dynamic conditions. Additionally, the mechanism used by the complex to modulate the genes $(r p f, g u m B, c l p$ and $m a n A)$ involved in the biofilm formation and stability was also studied. Our results demonstrated that Xcc $\varphi 1$, alone or in combination with 6PP and HA, interfered with the gene pathways involved in the formation of biofilm. This approach can be used as a model for other biofilm-producing bacteria.
\end{abstract}

Keywords: Xanthomonas campestris pv. campestris; 6-pentyl- $\alpha$-pyrone; antibiosis; Trichoderma; secondary metabolites; antibiofilm; Gram-negative bacterium; antibiotic resistance

\section{Introduction}

The Gram-negative bacterium Xanthomonas campestris pv. campestris (Xcc) is the causal agent of black-rot disease in crucifers, responsible for serious yield losses worldwide [1]. The bacterial secretion composed of exopolysaccharides can obstruct the xylem vessels, causing tissue necrosis and leaf wilting [2]. The Xcc produces a variety of substances, such as enzymes, that may be used by this bacterium to parasitize the host [3].

At present, the ongoing spread of antibiotic-resistant bacteria is a major public health concern that is further exacerbated by some agricultural management practices [4]. The bacterial contamination of food surfaces is the main cause of food-borne illnesses [5]. The mechanism mainly used by bacteria to improve its chance of survival, especially in weakly resistant isolates, is the formation of biofilm [6], 
an extracellular polymeric matrix composed of proteins, polysaccharides and DNA [7]. In this context, emerging issues in the management of infections caused by antibiotic-resistant and biofilm-forming bacteria have encouraged the development of alternative therapeutic approaches [8,9].

Several studies highlight the efficacy of lytic phages against bacteria $[10,11]$; however, antiphage resistance mechanisms may limit their activity [12]. We believe that this strategy, combined with the application of metabolites obtained from a specific (or given) fungus, might be a potential alternative in the prevention and control of biofilm-related infections. Thus, Trichoderma, a well-known beneficial fungus, was selected for its plant growth promotion [13] and biocontrol abilities [14]. The species T. atroviride produces a natural compound, known as 6-pentyl- $\alpha$-pyrone (6PP), with interesting properties (i.e., antibiotic, plant metabolome interference) [13,15].

Interactions between biomolecules and different kinds of inorganic surfaces, like hydroxyapatite (HA) nanocrystals, biogenic silica, carbonates and phosphates, are important in numerous biological applications, such as drug and gene delivery, a possible way to selectively release prodrug in tumor tissues, and antimicrobial molecule carriers [16-18]. Previous studies have demonstrated that HA nanocrystals, a mineral rich in $\mathrm{Ca}_{10}\left(\mathrm{PO}_{4}\right)_{6}(\mathrm{OH})_{2}$, can be used for bacteriophage delivery and as an enhancer of its biological activities and stability [16]. Therefore, HA may act as carrier of antimicrobial compounds [17] and as a factor to improve lytic activity of bacteriophages [16], adsorbing molecules as well as particles [18].

This is the first study to describe the antibiofilm activity of 6PP, alone and in association with a phage and hydroxyapatite (a biocompatible mineral) against Xcc. This association may overcome the problems arising from the formation of bacterial biofilm during infection. In particular, the antibiofilm activity of 6PP helps the phage to better interact with and lyse the bacteria, and the HA can be considered as a potential carrier for the active principles.

\section{Materials and Methods}

\subsection{Isolation and Growth of Xcc Phages}

Ten grams of rhizospheric soil collected from different kohlrabi (Brassica oleracea var. gongylodes) plants showing black rot symptoms was suspended in $15 \mathrm{~mL}$ of nutrient broth (Sigma Aldrich) and agitated for $30 \mathrm{~min}$ at $20^{\circ} \mathrm{C}$. Soil sediment was removed by centrifugation (5.000 rpm for $\left.20 \mathrm{~min}\right)$, and the supernatants were transferred to sterile flasks. Xcc was incubated overnight at $24^{\circ} \mathrm{C}$ under shaking conditions. Cultures were centrifuged and filtered through a $0.22 \mu \mathrm{m}$ pore-size membrane filter (MF-Millipore, Darmstadt, Germany). The filtrates were assayed for the presence of Xcc-infecting phage by plating a $10 \mu \mathrm{L}$ aliquot on soft agar. After $48 \mathrm{~h}$, plaque-forming units (PFU) of phage were picked and resuspended in distilled water, incubated at $37^{\circ} \mathrm{C}$ for $4 \mathrm{~h}$, centrifuged at $5000 \mathrm{rpm}$ for $30 \mathrm{~min}$ and filtered as mentioned above [19]. The experiment was repeated five times.

\subsection{Complex $\varphi H A 6 P P$}

The $\varphi$ HA6PP complex was prepared by mixing $1 \mathrm{~mL}$ of HA $(100 \mathrm{mg} / \mathrm{mL})$ with $1 \mathrm{~mL}$ of $\mathrm{Xcc} \varphi 1$ $\left(10^{8} \mathrm{PFU} / \mathrm{mL}\right)$ and varying concentrations of $6 \mathrm{PP}(0.02,0.01,0.004,0.002,0.001,0.0004$ and $0.0002 \mu \mathrm{g} / \mathrm{mL}$ solubilized in dimethyl sulfoxide (DMSO)). A control sample with the solvents alone was also prepared. The mixture was incubated at room temperature, under shaking conditions, for time periods of 0 , 30, 90, 180 and $300 \mathrm{~min}$ and $24 \mathrm{~h}$. Later, samples were centrifuged, and the pellet was suspended in distilled water. A further centrifugation step was carried out, and the supernatant was screened for the presence and concentration of phage particles using the double-layer agar (DLA) method [16]. After overnight incubation at $24^{\circ} \mathrm{C}$, the optimal incubation time was selected.

\subsection{Isolation of 6-Pentyl- $\alpha$-pyrone}

The biocontrol fungus $T$. atroviride strain P1 was maintained on potato dextrose agar (PDA, Sigma St. Louis, MO, USA) Petri plates at room temperature and sub-cultured bimonthly. 
Six $5 \mathrm{~mm}$ diameter plugs were collected from the actively growing margins of the PDA cultures and inoculated into $5 \mathrm{~L}$ conical flasks containing $1 \mathrm{~L}$ of sterile potato dextrose broth (PDB, Sigma). The stationary cultures were incubated at $25^{\circ} \mathrm{C}$ for 21 days. The cultures were vacuum filtered through filter paper (Whatman No. 4; Brentford, UK). The culture broth of T. atroviride strain P1 was extracted exhaustively with ethyl acetate (EtOAc). The red-brown residue was subjected to flash column chromatography (Si gel; $50 \mathrm{~g}$ ) by eluting with a gradient of EtOAc:Petroleum ether (8:2 to 10:0). Analytical thin-layer chromatography (TLC) was performed, and fractions were further purified by using silica-gel flash chromatography (Kieselgel $60, \mathrm{GF}_{254}, 0.25$ and $0.5 \mathrm{~mm}$, Merck Darmstadt, Germany). Compounds were detected with UV radiation ( 254 or $366 \mathrm{~nm}$ ) and by dipping the TLC plates in a $10 \%(w / v)$ aqueous solution of $\mathrm{CeSO}_{4}$ or in a $5 \%(v / v)$ ethanol solution of $\mathrm{H}_{2} \mathrm{SO}_{4}$ and heating at $110{ }^{\circ} \mathrm{C}$ for $10 \mathrm{~min}$. Pure metabolite was characterized by LC/MS q-TOF analysis recorded with an Agilent system (HPLC 1260 Infinity Series) coupled to a q-TOF mass spectrometer Model G6540B with a dual electrospray ionization source and equipped with a DAD system (Agilent Technologies, Santa Clara, CA, USA). This compound showed the same spectrometric data of an authentic standard previously isolated in our laboratories [15].

\subsection{Antibiofilm Activity of 6-Pentyl- $\alpha$-pyrone}

The biofilm formation was measured using crystal violet staining. The experiment was performed to characterize the antibiofilm activity of different concentrations of $6 \mathrm{PP}$ on mature biofilm. A $200 \mu \mathrm{L}$ of $\mathrm{Xcc}$ was added to each well using a 96-well plate (Falcon), and incubated at $24{ }^{\circ} \mathrm{C}$ for $72 \mathrm{~h}$ under static conditions to allow bacterial attachment and the biofilm formation. Then, $6 \mathrm{PP}$ was added at different concentrations to the complex. After $4 \mathrm{~h}$, the samples were analyzed as previously reported [20].

\subsection{CLSM Analysis for Static Biofilm Evaluation}

Confocal laser scanning microscopy (CLSM) of Xcc biofilms was performed on Nunc Lab-Tek eight-well Chamber Slides (No. 177445; Thermo Scientific, Ottawa, ON, Canada). The overnight cultures of Xcc were diluted to a cell concentration of about 0.001 (OD) $600 \mathrm{~nm}$. The bacterial culture was incubated at $24{ }^{\circ} \mathrm{C}$ for $96 \mathrm{~h}$ to allow the Xcc biofilm to form. In order to assess the antibiofilm activity and the influence on cell viability of treatments, the mature biofilms were incubated for $4 \mathrm{~h}$ and treated as follows: (1) with 6PP $(0.001 \mu \mathrm{g} / \mathrm{mL})$; (2) without $6 \mathrm{PP}$; (3) with the phage alone $\left(10^{8} \mathrm{PFU} / \mathrm{mL}\right)$; (4) with the complex of phage $\left(10^{8} \mathrm{PFU} / \mathrm{mL}\right)$ plus HA $(10 \mathrm{mg} / \mathrm{mL})$ and $6 \mathrm{PP}(0.001 \mu \mathrm{g} / \mathrm{mL})$. The lowest concentration of 6PP showing the maximum efficacy in combination was selected for the experiments. The biofilm cell and the microscopic observations were performed as previously reported [21].

\subsection{CLSM Analysis for Dynamic Biofilm Evaluation}

The analysis of Xcc biofilms was performed using a three-channel flow cell chamber (IBI Scientific, Peosta, IA). A solution of phosphate-buffered saline (PBS, pH 7) was introduced into each channel of the cell at a controlled flow rate of $160 \mu \mathrm{L} / \mathrm{min}$ using an Ismatec IPC 4 peristaltic pump (Cole-Parmer $\mathrm{GmbH}$, Germany). The flow system was kept free of air bubbles using a bubble trap, which created low positive pressure under the PBS flow. Then, a bacterial suspension of Xcc at optical density of $0.5 \mathrm{~mL}^{-1}$ was left in circulation through the system for $2 \mathrm{~h}$, and the non-adhering cells were removed using sterile PBS for $15 \mathrm{~min}$. Finally, fresh medium (nutrient broth 50\% v/v in PBS) was put through the system for $48 \mathrm{~h}$ to allow biofilm formation. After incubation, treatments of fresh medium (NT), $6 \mathrm{PP}(0.001 \mu \mathrm{g} / \mathrm{mL})$ or the $\varphi$ HA6PP complex was circulated separately for $3 \mathrm{~h}$ into each cell channel. The biofilm formation was evaluated by CLSM. The biofilm cell viability and microscopic observations were determined as previously reported [22].

\subsection{RNA Extraction and Expression Profiling by $q P C R$}

Fifty milliliters of Xcc was incubated at $24{ }^{\circ} \mathrm{C}$ for $72 \mathrm{~h}$ in a narrow-mouth glass Erlenmeyer flask under static conditions. Then, the phage $\left(10^{8} \mathrm{PFU} / \mathrm{mL}\right), 6 \mathrm{PP}(0.001 \mu \mathrm{g} / \mathrm{mL})$ and $\varphi \mathrm{HA} 6 \mathrm{PP}$ were added 
to each sample. Ten milliliters of biofilm were collected after 30, 60, 90 and $120 \mathrm{~min}$. Total RNA was extracted using the TRIzol protocol [23]. A NanoDrop ND-1000 (Thermo Fisher Scientific Inc.) was used to assess total RNA quantity. One microgram of purified total RNA was used as a template for first-strand cDNA synthesis using SuperScript III Reverse Transcriptase (Invitrogen). The primers were designed using the tool provided at https:/www.eurofinsgenomics.eu/en/ecom/tools/qpcr-assaydesign/ for all genes (Supplementary Table). Gene transcript levels were measured using Power SYBR Green PCR Master Mix as previously reported [24]. Thermocycler conditions were as follows: initial step at $95^{\circ} \mathrm{C}$ for $10 \mathrm{~min}, 40$ cycles of $95^{\circ} \mathrm{C}$ for $15 \mathrm{~s},\left(\operatorname{clp} 57.1^{\circ} \mathrm{C}\right.$; man $\left.A 55^{\circ} \mathrm{C}, \operatorname{rpf} 59.9{ }^{\circ} \mathrm{C}, \operatorname{gumB} 63.7^{\circ} \mathrm{C}\right)$ for $40 \mathrm{~s}$ and $72^{\circ} \mathrm{C}$ for $1 \mathrm{~min}$. All samples were normalized to $\mathrm{HcrC}$ as the reference housekeeping gene. The relative quantitative expression was determined using the $2^{-\Delta \Delta C T}$ method [25].

\section{Results}

\subsection{Antibiofilm Activity of 6-Pentyl- $\alpha$-pyrone}

The antibiofilm activity of $6 \mathrm{PP}$ alone and the complex $\varphi$ HA6PP were evaluated against Xcc. The complex $\varphi \mathrm{HA} 6 \mathrm{PP}$ limited the biofilm formation more efficiently than $6 \mathrm{PP}$ used alone. The $6 \mathrm{PP}$ at a concentration of $0.001 \mu \mathrm{g} / \mathrm{mL}$ disrupted the biofilm by about $70 \%$. The DMSO (used as solvent of 6PP at $0.1 \%$ concentration) did not interfere with biofilm integrity (Figure 1 ).

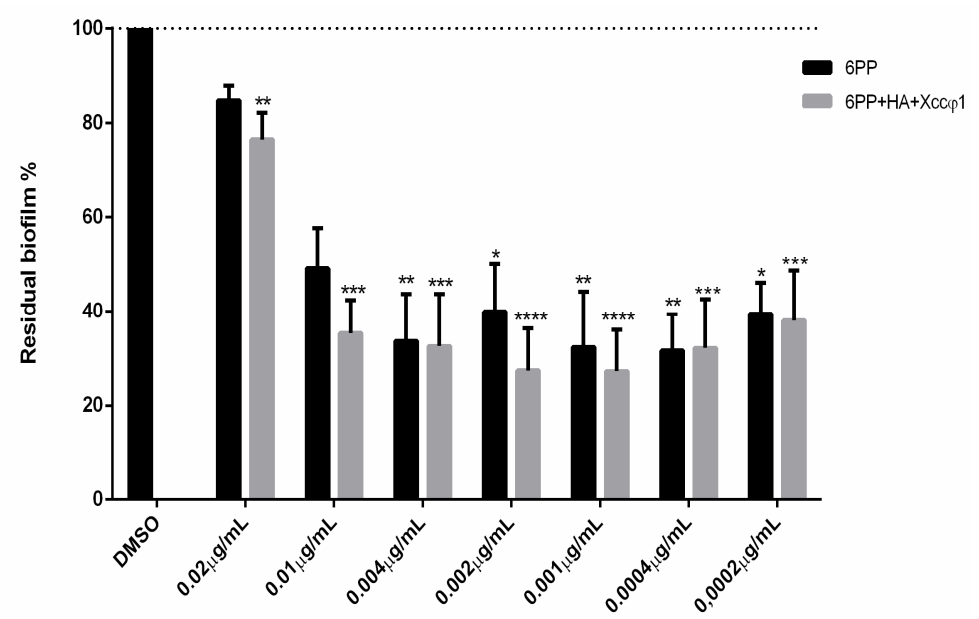

Figure 1. Antibiofilm activities of different concentrations of 6-pentyl- $\alpha$-pyrone (6PP) alone, and in the complex of $6 \mathrm{PP}+$ hydroxyapatite and Xanthomonas campestris $\mathrm{pv}$. campestris phage (Xcc $\varphi 1)$. Biofilm was assessed after $72 \mathrm{~h}$ of incubation at $25^{\circ} \mathrm{C}$ using a crystal violet assay. The data are expressed as percentages of residual biofilm. Values represent the mean \pm SD of the three independent experiments. Absorbance, compared to the untreated control, was considered statistically significant with $p<0.05$ (* $\left.p<0.05,{ }^{* *} p<0.01,{ }^{* * *} p<0.001,{ }^{* * * *} p<0.0001\right)$ according to two-way ANOVA multiple comparisons.

\subsection{CLSM Analysis for Static Biofilm Evaluation}

CLSM analysis confirmed the results obtained from the crystal violet test. As shown in Figure 2, the $6 \mathrm{PP}(0.001 \mu \mathrm{g} / \mathrm{mL})$ and the phage, when used alone, caused a small reduction in the biofilm mass. However, when 6PP was combined with phage and HA, there was a consistent reduction in biofilm formation. 


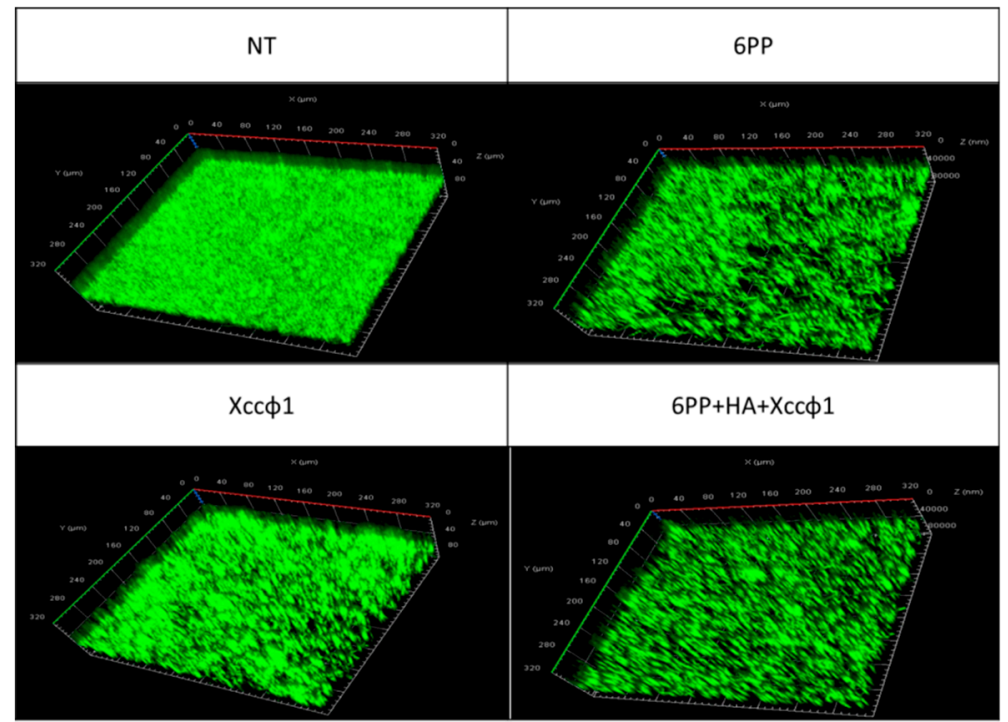

Figure 2. Confocal laser scanning microscopy (CLSM) observation of biofilm formation of Xanthomonas campestris pv. campestris under static conditions. The treatments were fresh medium, no treatment (NT); 6-pentyl- $\alpha$-pyrone (6PP, $0.001 \mu \mathrm{g} / \mathrm{mL})$; Xanthomonas campestris pv. campestris phage (Хсc $\varphi 1)$; and the complex of 6PP, hydroxyapatite (HA) plus Хсс $\varphi 1$. Biofilm analysis was carried out on mature biofilm after $72 \mathrm{~h}$ of incubation at $24{ }^{\circ} \mathrm{C}$. The three-dimensional biofilm structure was demonstrated using the LIVE/DEAD Biofilm Viability kit.

\subsection{CLSM Analysis for Dynamic Biofilm Evaluation}

In order to reproduce the plant xylem, the Xcc biofilm formation was investigated using a three-channel flow cell system. The phage alone did not show significant disruption of the biofilm structure. The $6 \mathrm{PP}(0.001 \mu \mathrm{g} / \mathrm{mL})$ used alone partially disrupted the biofilm structure. However, the biofilm mass was almost totally unstructured when 6PP was combined with the phage and HA (Figure 3). The CLSM fluidic system confirmed the antibiofilm activity of $\varphi$ HA6PP.

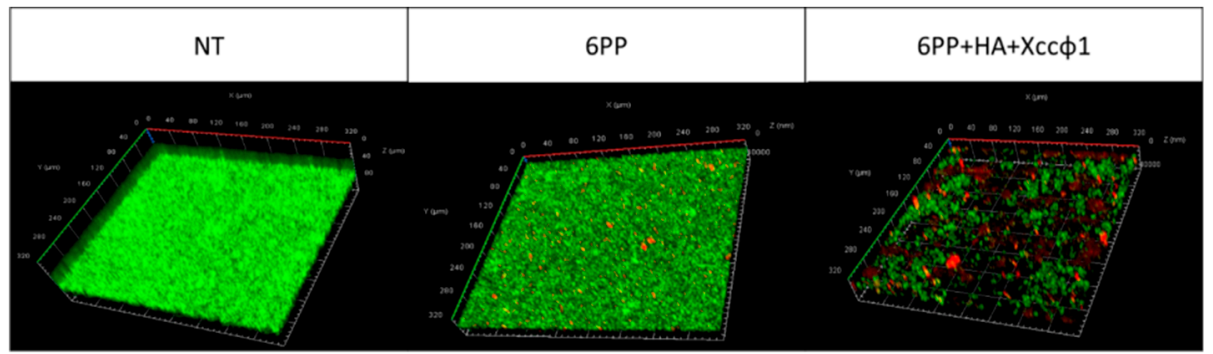

Figure 3. Confocal laser scanning microscopy analysis demonstrating biofilm formation of Xanthomonas campestris pv. campestris under dynamic conditions. The three treatments were fresh medium-no treatment (NT); 6-pentyl- $\alpha$-pyrone $(6 \mathrm{PP}, 0.001 \mu \mathrm{g} / \mathrm{mL})$; and the complex of 6PP, hydroxyapatite (HA) plus Xanthomonas campestris pv. campestris phage (Xсc $\varphi 1)$. Biofilm formation was performed using a three-channel flow cell. The three-dimensional biofilm structures were obtained using the LIVE/DEAD Biofilm Viability kit.

\subsection{RNA Extraction and Expression Profiling by $q P C R$}

The expression levels were evaluated of four principal genes ( $r p f, g u m B, c l p$ and $m a n A)$ involved in the biofilm production pathways. The gene $r p f$ positively regulates the synthesis of extracellular enzymes and extracellular polymeric substance (EPS) as well as several essential factors of pathogenicity and diffusible signal factor (DSF) [26]. The gene clp is essential in DSF production, and it is highly conserved in Xcc [27]. The gene gumB is involved in the assemblage of pentasaccharides, 
transfer of nonglycosidic constituents and export of xanthan [26]. Finally, the gene man $A$ encodes several mannase enzymes, including mannan endo-1,4- $\beta$-mannosidase, which is a dispersing biofilm enzyme of Xcc. Analysis by qPCR showed a significant upregulation of $r p f$, gumB and $c l p$ genes $30 \mathrm{~min}$ after treatment, and the complex $\varphi$ HA6PP induced the highest level of upregulation $(p<0.05)$. Interestingly, the upregulation of $\operatorname{man} A$ was cyclical (every $30 \mathrm{~min}$ ) (Figure 4).
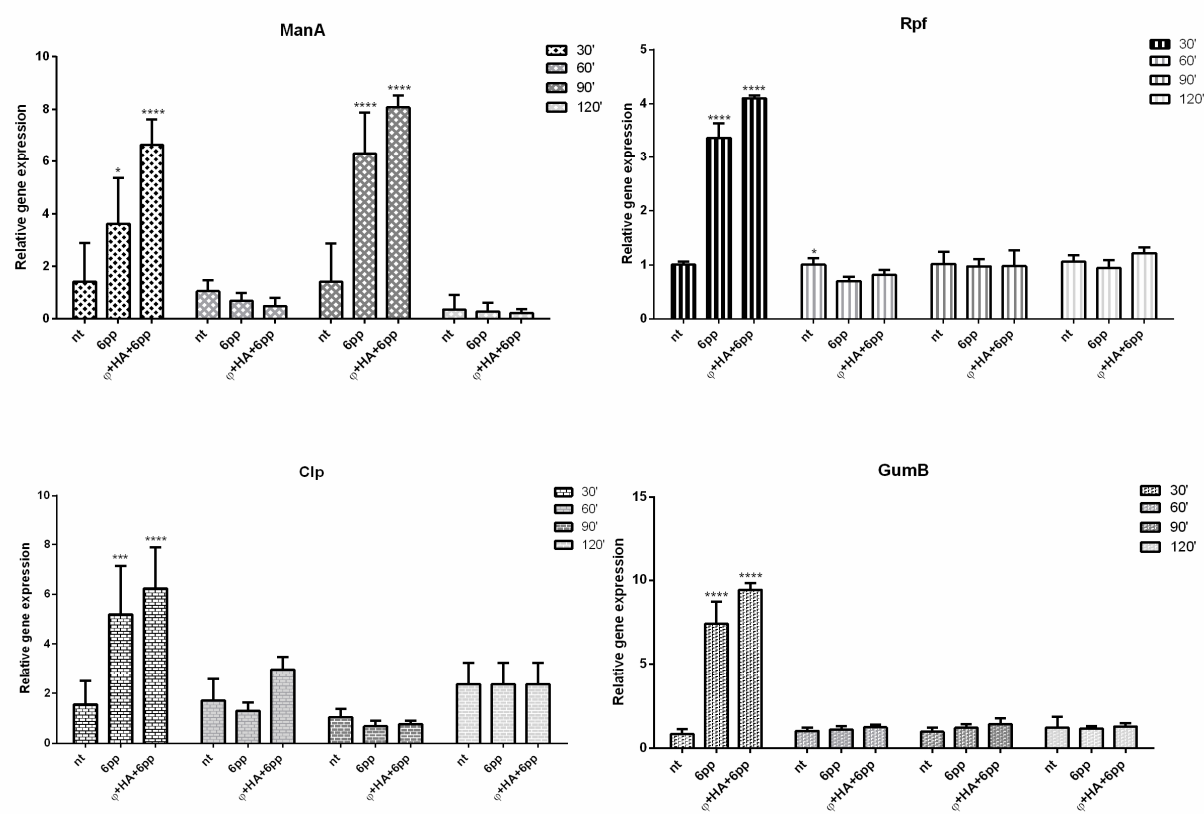

Figure 4. The expression profiles of the four genes ( $r p f$ at top right; gumB at bottom right; $c l p$ at bottom left; manA at top left) of Xanthomonas campestris pv. campestris by quantitative real-time PCR (qPCR). Biofilm samples untreated (NT), treated with 6-pentyl- $\alpha$-pyrone (6PP); and the complex of hydroxyapatite, $6 \mathrm{PP}$ and Xanthomonas campestris pv. campestris phage $(\varphi \mathrm{HA} 6 \mathrm{PP})$ were analyzed after 30, 60, 90 and $120 \mathrm{~min}$. Statistical analysis was performed using two-way ANOVA multiple comparison test $\left({ }^{*} p<0.05,{ }^{* *} p<0.01,{ }^{* * *} p<0.001,{ }^{* * * *} p<0.0001\right)$. The gene HcrC was used as reference.

\section{Discussion}

Worldwide research on bacterial biofilms is proceeding on several diverse fronts, with particular emphasis on the investigation of specifically expressed genes, the role of biofilms in antimicrobial resistance, the evaluation of control measures and the development of innovative strategies.

Many molecules have antibiofilm properties as well as antimicrobial activities [28]. Specifically, we investigated the biofilm formation during Xcc growth that plays a key role in its infective process [27]. Our results suggested that $6 \mathrm{PP}$ did not show as much significant antibacterial activity against free-living Xcc as other bacteria in the biofilm matrix (data not shown). However, this molecule displayed an effective biofilm-dissolving ability. Herein, we are reporting for the first time on the antibiofilm activity of $6 \mathrm{PP}$, a secondary metabolite isolated from the culture filtrate of T. atroviride P1. Several species belonging to Trichoderma are widely known and recognized as biocontrol and biostimulant agents [29-31].

Additionally, the mineral HA is known to chemically interact not only with molecules but also with biological structures like bacteriophages [16]. In fact, the low degree of crystallinity and the presence of carbonate ions in the crystal structure make HA extremely reactive in biological systems and suitable for interaction with, and transportation of, bacteriophages. In this study, HA seems to work well as a carrier for $6 \mathrm{PP}$ and $\mathrm{Xcc} \varphi 1$ in order to increase their activities against the pathogenic bacteria.

The compound 6PP, alone or in combination with $Х \operatorname{cc} \varphi 1$ and HA, showed lower antibiofilm activity when applied at higher concentration (Figure 1, $0.02 \mathrm{mg} / \mathrm{mL}$ ). It is likely that higher doses of 6PP may interfere with the bacterial endosmosis processes of damaging the cell membranes [32]. 
Otherwise, it is possibly the formation of aggregates that makes the compound unable to penetrate the biofilm structure [33].

Generally, the complex $\varphi$ HA6PP was more efficient on biofilm under the dynamic rather than under the static conditions. This combination showed potentially valid properties for further in vivo tests.

The DSF biosynthesis is modulated by a novel post-translational mechanism involving protein-protein interaction between the two DSF clusters, synthase RpfF ( rpf) and sensor RpfC ( $g u m B)$ [34]. Further, the quorum sensing (QS) signal is coupled with several intracellular regulatory networks through the second messenger cyclic dimeric GMP and the global regulator clp (gene investigated). Genomic analysis shows that the DSF-QS signaling pathway regulates diverse biological functions including virulence, biofilm dispersal and ecological competence. Future investigations could be made into the DSF-QS system in plant and human bacterial pathogens [35].

The RpfC/RpfG two-component system plays a key role in DSF signal transduction and modulates downstream DSF regulon by changing intracellular content of cyclic dimeric GMP. The increase in the content of cyclic dimeric GMP can positively influence both $m a n A$, involved in biofilm dispersal, and $c l p$, associated with xanthan production by upregulating the gum genes $(g u m B)$ [34]. Figure 4 shows that, $30 \mathrm{~min}$ after $\varphi \mathrm{HA} 6 \mathrm{PP}$ treatment, all the genes are upregulated ( $r p f, c l p, g u m B$ and manA); this may be related to the promoter rpf. Interestingly, after $90 \mathrm{~min}$, only man $A$ is upregulated, in accordance to recent work demonstrating that the one-step growth curve of the phage completes its lytic cycle over the exact same period of time [35]. Moreover, manA is involved in mannose metabolism, for which the metabolic alteration activity of the phage on Xcc biofilm has been previously demonstrated [36]. Specifically, 30 min after treatment with the complex a stress signal, released from the bacteria activates all the pathways (studied) involved in biofilm formation. Subsequently, the activity of the phage, improved by HA and 6PP, may influence the manA synthesis in order to assist the biofilm dispersion. This hypothesis is supported by our results in which the treatment with the phage shows high levels of galactomannan that reduce the viscosity of the biofilm. This study highlights the ability of the complex to dysregulate the metabolic pathways via $\operatorname{man} A$, a gene involved in processes able to promote the mature biofilm dispersion, thus making the bacterial aggregate more penetrable. For these reasons, the $\varphi$ HA6PP complex seems to work as a DSF molecule, able to activate manA expression. Furthermore, the interference on metabolic pathways involved in biofilm formation due to Xcc $\varphi 1$, alone or in combination with HA and eicosanoic acid, has been demonstrated [36]. Our results have provided evidence that the $\varphi$ HA6PP complex modifies the biofilm structure and production, thus probably interacts by biofilm solubilisation.

In conclusion, this study demonstrates that the $\varphi \mathrm{HX6PP} \mathrm{complex} \mathrm{interferes} \mathrm{with} \mathrm{biofilm} \mathrm{production}$ and promotes the mature biofilm dispersion of Xcc. This approach may represent a novel strategy for biofilm prevention and control of plant pathogenic bacteria.

Author Contributions: Conceptualization, F.V. and R.C.; methodology, M.P., A.R. and A.Z.; validation, S.L.W. and M.L.; formal analysis, M.P., A.F. and A.R.; investigation, M.P.; data curation, G.d. and M.P.; writing-original draft preparation, M.P., G.d. and F.V.; writing-review and editing, F.V., M.L., S.L.W. and R.C.; supervision, R.C. and F.V.; project administration, F.V. and M.L. All authors have read and agreed to the published version of the manuscript.

Funding: The study was supported by MIURPON grant Marea 03PE_00106, POR FESR CAMPANIA 2014/2020O.S. 1.1 grant Bioagro 559, MISE CRESO Protection n. F/050421/01-03/ X32, PSR Veneto 2014/2020 Misura 16-Tipologia di intervento 16.1-Azione 2 "Sostegno ai Progetti Operativi di Innovazione (POI)"-Divine n. 3589659, PSR Campania 2014/2020 Misura 16-Tipologia di intervento 16.1-Azione 2 "Sostegno ai Progetti Operativi di Innovazione (POI)" — Progetto "DI.O.N.IS.O.", C.U.P. B98H19005010009 and MIURPON grant Linfa 03PE_00026_1.

Conflicts of Interest: The authors declare no conflict of interest. 


\section{References}

1. Qian, W.; Jia, Y.; Ren, S.X.; He, Y.Q.; Feng, J.X.; Lu, L.F.; Wu, W. Comparative and functional genomic analyses of the pathogenicity of phytopathogen Xanthomonas campestris pv. campestris. Genome Res. 2005, 15, 757-767. [CrossRef] [PubMed]

2. Liao, C.T.; Chiang, Y.C.; Hsiao, Y.M. Functional characterization and proteomic analysis of lolA in Xanthomonas campestris pv. campestris. BMC Microbiol. 2019, 19, 20. [CrossRef] [PubMed]

3. Dow, J.M.; Daniels, M.J. Pathogenicity determinants and global regulation of pathogenicity of Xanthomonas campestris pv. campestris. Curr. Top. Microbiol. Immunol. 1994, 192, 29-41. [PubMed]

4. Li, B.; Webster, T.J. Bacteria antibiotic resistance: New challenges and opportunities for implant-associated orthopedic infections. J. Orthop. Res. 2018, 36, 22-32. [CrossRef]

5. Windler, M.; Leinweber, K.; Bartulos, C.R.; Philipp, B.; Kroth, P.G. Biofilm and capsule formation of the diatom Achnanthidium minutissimum are affected by a bacterium. J. Phycol. 2015, 51, 343-355. [CrossRef]

6. Cepas, V.; López, Y.; Munoz, E.; Rolo, D.; Ardanuy, C.; Martí, S.; Soto, S.M. Relationship between biofilm formation and antimicrobial resistance in gram-negative bacteria. Microb. Drug Resist. 2019, 25, 72-79. [CrossRef]

7. Donlan, R.M. Preventing biofilms of clinically relevant organisms using bacteriophage. Trends Microbiol. 2009, 17, 66-72. [CrossRef]

8. Stewart, P.S.; William Costerton, J. Antibiotic resistance of bacteria in biofilms. Lancet 2001, 358, $135-138$. [CrossRef]

9. Del Pozo, J.L.; Patel, R. The challenge of treating biofilm-associated bacterial infections. Clin. Pharmacol. Ther. 2007, 82, 204-209. [CrossRef]

10. Harper, D.R.; Parracho, H.M.; Walker, J.; Sharp, R.; Hughes, G.; Werthén, M.; Morales, S. Bacteriophages and biofilms. Antibiotics 2014, 3, 270-284. [CrossRef]

11. Gutiérrez, D.; Vandenheuvel, D.; Martínez, B.; Rodríguez, A.; Lavigne, R.; García, P. Two phages, phiIPLA-RODI and phiIPLA-C1C, lyse mono-and dual-species staphylococcal biofilms. Appl. Environ. Microbiol. 2015, 81, 3336-3348. [CrossRef] [PubMed]

12. Pires, D.P.; Melo, L.D.R.; Vilas Boas, D.; Sillankorva, S.; Azeredo, J. Phage therapy as an alternative or complementary strategy to prevent and control biofilm-related infections. Curr. Opin. Microbiol. 2017, 39, 48-56. [CrossRef] [PubMed]

13. Vinale, F.; Sivasithamparam, K.; Ghisalberti, E.L.; Marra, R.; Barbetti, M.J.; Li, H.; Woo, S.L.; Lorito, M. A novel role for Trichoderma secondary metabolites in the interactions with plants. Physiol. Mol. Plant Pathol. 2008, 72, 80-86. [CrossRef]

14. Marra, R.; Ambrosino, P.; Carbone, V.; Vinale, F.; Woo, S.L.; Ruocco, M.; Gigante, S. Study of the three-way interaction between Trichoderma atroviride, plant and fungal pathogens by using a proteomic approach. Curr. Genet. 2006, 50, 307-321. [CrossRef]

15. Pascale, A.; Vinale, F.; Manganiello, G.; Nigro, M.; Lanzuise, S.; Ruocco, M.; Lorito, M. Trichoderma and its secondary metabolites improve yield and quality of grapes. Crop Prot. 2017, 92, S11-S12. [CrossRef]

16. Fulgione, A.; Ianniello, F.; Papaianni, M.; Contaldi, F.; Sgamma, T.; Giannini, C.; Lelli, M. Biomimetic hydroxyapatite nanocrystals are an active carrier for Salmonella bacteriophages. Int. J. Nanomed. 2019, 14, 2219-2232. [CrossRef]

17. Nocerino, N.; Fulgione, A.; Iannaccone, M.; Tomasetta, L.; Ianniello, F.; Martora, F.; Capparelli, R. Biological activity of lactoferrin-functionalized biomimetic hydroxyapatite nanocrystals. Int. J. Nanomed. 2014, 9, 1175-1184.

18. Fulgione, A.; Nocerino, N.; Iannaccone, M.; Roperto, S.; Capuano, F.; Roveri, N.; Capparelli, R. Lactoferrin adsorbed onto biomimetic hydroxyapatite nanocrystals controlling-in vivo-the Helicobacter pylori infection. PLoS ONE 2016, 11. [CrossRef]

19. Cross, T.; Schoff, C.; Chudoff, D.; Graves, L.; Broomell, H.; Terry, K.; Dunbar, D. An optimized enrichment technique for the isolation of Arthrobacter bacteriophage species from soil sample isolates. J. Vis. Exp. 2015. [CrossRef]

20. Papaianni, M.; Contaldi, F.; Fulgione, A.; Woo, S.L.; Casillo, A.; Corsaro, M.M.; Garonzi, M. Role of phage $\phi 1$ in two strains of Salmonella Rissen, sensitive and resistant to phage $\phi 1$. BMC Microbiol. 2018, 18, 208. [CrossRef] 
21. Casillo, A.; Papa, R.; Ricciardelli, A.; Sannino, F.; Ziaco, M.; Tilotta, M.; Artini, M. Anti-Biofilm activity of a long-chain fatty aldehyde from antarctic Pseudoalteromonas haloplanktis TAC125 against Staphylococcus epidermidis biofilm. Front. Cell. Infect. Microbiol. 2017, 7, 46. [CrossRef]

22. Casillo, A.; Ziaco, M.; Lindner, B.; Parrilli, E.; Schwudke, D.; Holgado, A.; Tutino, M.L. Unusual Lipid A from a cold-adapted Bacterium: Detailed structural characterization. ChemBioChem 2017, 18, 1845-1854. [CrossRef]

23. Rio, D.C.; Ares, M.; Hannon, G.J.; Nilsen, T.W. Purification of RNA using TRIzol (TRI reagent). Cold Spring Harb. Protoc. 2010, 2010, pdb.prot5439. [CrossRef]

24. Allam, A.F.; Farag, H.F.; Zaki, A.; Kader, O.A.; Abdul-Ghani, R.; Shehab, A.Y. Detection of low-intensity Schistosoma mansoni infection by Percoll sedimentation and real-time PCR techniques in a low-endemicity Egyptian setting. Trop. Med. Int. Heal. 2015, 20, 658-664. [CrossRef]

25. Livak, K.J.; Schmittgen, T.D. Analysis of relative gene expression data using real-time quantitative PCR and the 2- $\Delta \Delta$ CT method. Methods 2001, 25, 402-408. [CrossRef]

26. Dow, J.M.; Crossman, L.; Findlay, K.; He, Y.Q.; Feng, J.X.; Tang, J.L. Biofilm dispersal in Xanthomonas campestris is controlled by cell-cell signaling and is required for full virulence to plants. Proc. Natl. Acad. Sci. USA 2003, 100, 10995-11000. [CrossRef]

27. Ryan, R.P.; Dow, J.M. Communication with a growing family: Diffusible signal factor (DSF) signaling in bacteria. Trends Microbiol. 2011, 19, 145-152. [CrossRef]

28. Chung, P.Y.; Khanum, R. Antimicrobial peptides as potential anti-biofilm agents against multidrug-resistant bacteria. J. Microbiol. Immunol. Infect. 2017, 50, 405-410. [CrossRef]

29. Harman, G.E. Multifunctional fungal plant symbionts: New tools to enhance plant growth and productivity. New Phytol. 2011, 189, 647-649. [CrossRef]

30. Harman, G.E.; Howell, C.R.; Viterbo, A.; Chet, I.; Lorito, M. Trichoderma species-Opportunistic, avirulent plant symbionts. Nat. Rev. Microbiol. 2004, 2, 43-56. [CrossRef]

31. Mukherjee, P.K.; Horwitz, B.A.; Herrera-Estrella, A.; Schmoll, M.; Kenerley, C.M. Trichoderma research in the genome era. Annu. Rev. Phytopathol. 2013, 51, 105-129. [CrossRef]

32. Ozkan, A.; Erdogan, A. A comparative study of the antioxidant/prooxidant effects of carvacrol and thymol at various concentrations on membrane and DNA of parental and drug resistant H1299 cells. Nat. Prod. Commun. 2012, 7, 1557-1560. [CrossRef]

33. Lewis, K. Riddle of biofilm resistance. Antimicrob. Agents Chemother. 2001, 45, 999-1007. [CrossRef]

34. Torres, P.S.; Malamud, F.; Rigano, L.A.; Russo, D.M.; Marano, M.R.; Castagnaro, A.P.; Vojnov, A.A. Controlled synthesis of the DSF cell-cell signal is required for biofilm formation and virulence in Xanthomonas campestris. Environ. Microbiol. 2007, 9, 2101-2109. [CrossRef]

35. Papaianni, M.; Paris, D.; Woo, S.L.; Fulgione, A.; Rigano, M.M.; Parrilli, E.; Limone, A. Plant dynamic metabolic response to bacteriophage treatment after Xanthomonas campestris pv. campestris infection. Front. Microbiol. 2020, 11, 732. [CrossRef]

36. Papaianni, M.; Cuomo, P.; Fulgione, A.; Albanese, D.; Gallo, M.; Paris, D.; Motta, A.; Iannelli, D.; Capparelli, R. Bacteriophages promote metabolic changes in bacteria biofilm. Microorganisms 2020, 8, 480. [CrossRef]

(C) 2020 by the authors. Licensee MDPI, Basel, Switzerland. This article is an open access article distributed under the terms and conditions of the Creative Commons Attribution (CC BY) license (http://creativecommons.org/licenses/by/4.0/). 